\title{
ANALISIS KESEIMBANGAN HARGA DAGING AYAM BROILER DI PROPINSI JAWA TENGAH
}

(Analysis of the System Price Balance on Demand Curve of Commodity Broiler Meat In

Central Java)

\author{
Nurdayati $^{1}$ \\ 1). Staf Pengajar Sekolah Tinggi Penyuluhan Pertanian Magelang \\ Jl.Magelang-Kopeng Km 7 Tegalrejo Magelang \\ E-mail : nurd4y4t1@gmail.com;
}

Diterima : 11 Oktober 2015 Disetujui : 25 November 2015

\begin{abstract}
This study aimed to analyze the balance system price on the demand curve and the supply curve of commodity broiler meat in Central Java. Analysis of data using Cobweb equilibrium model. The results show Using cobweb balance, the magnitude of price elasticity of demand for broiler meat has a negative sign and is in elastic $(e<1)$, where as the supply elasticity which has a positive sign and have the elastic properties. It gives the sense that of consumer behavior with the change in the price of its impact on the quantity demanded of the smaller being on the side of the producers for its influence on the price changes of goods produced greater
\end{abstract}

Keywords :price, broiler, meat

\begin{abstract}
ABSTRAK
Penelitian ini bertujuan untuk Menganalisis Sistem keseimbangan harga pada kurva permintaan dan kurva penawaran komoditi daging ayam broiler di Jawa Tengah. Analisis data menggunakan model keseimbangan COBWEB. Hasilnya menunjukkan Menggunakan keseimbangan cobweb, besarnya elastisitas harga permintaan daging ayam broiler mempunyai tanda yang negatif dan bersifat in elastik (e $<1$ ), sedangkan elastisitas penawaran yang mempunyai tanda positif dan mempunyai sifat elastic. Ini memberikan arti bahwa dari perilaku konsumen dengan adanya perubahan harga pengaruhnya terhadap jumlah barang yang diminta lebih kecil sedang dari sisi produsen adanya perubahan harga pengaruhnya terhadap barang yang diproduksi lebih besar.
\end{abstract}

Kata Kunci: Daging ayam broiler, keseimbangan harga

\section{PENDAHULUAN}

\section{Latar Belakang Masalah}

Meningkatnya tingkat pendapatan dan jumlah penduduk, menyebabkan permintaan akan produk peternakan meningkat pula, seperti daging sapi, daging ayam, telur, dan susu. Hal tersebut dapat menimbulkan ketimpangan atau kekurangan antara jumlah pasokan produksi dengan jumlah kebutuhan yang diminta pada komoditas peternakan (Badan Pusat Statistik, 2000)

Daging ayam broiler merupakan salah satu pangan yang memiliki peranan strategis dan bernilai ekonomis serta mempunyai peluang untuk dikembangkan. di Propinsi Jawa Tengah daging ayam broiler 
mempunyai peranan yang cukup penting karena kemampuannya sebagai penyedia daging paling besar jumlahnya apabila dibanding dengan daging lainnya. Dari tahun 2008 - 2010 tercatat daging ayam broiler menduduki urutan pertama selanjutnya daging sapi dan sebagai urutan ketiga daging ayam buras kemudian baru daging lainnya. (Badan Pusat Statistik, 2010). Meningkatnya produksi daging ayam broiler ini merupakan alternatif sumber pendapatan bagi masyarakat.

Konsumen pada dasarnya menginginkan agar harga suatu barang turun, sedangkan produsen menginginkan agar harga suatu barang naik. Apabila kedua sisi dipertemukan maka diperoleh suatu titik tengah yang disebut dengan titik keseimbangan. Titik keseimbangan adalah harga dimana produsen memperoleh keuntungan yang maksimum, sedangkan konsumen memperoleh kepuasan maksimum. Untuk mengetahui apakah harga daging ayam broiler di Propinsi Jawa Tengah telah memberikan kepuasan bagi konsumen dan keuntungan bagi produsen maka perlu adanya penelitian untuk mengetahui keseimbangan harga daging broiler di Propinsi Jawa Tengah.

\section{Tujuan Penelitian}

Menganalisis Sistem keseimbangan harga pada kurva permintaan dan kurva penawaran komoditi daging ayam broiler di Jawa Tengah

\section{Landasan Teori}

Persamaan Simultan Fungsi Permintaan dan Penawaran

Fungsi permintaan:

$\mathrm{Q}_{\mathrm{D}}=\mathrm{D}(\mathrm{P}, \alpha)$
Keterangan: $\mathrm{Q}_{\mathrm{D}}=$ jumlah permintaan, $\mathrm{P}=$ harga barang, dan $\alpha=$ variabel yang dimungkinkan dapat menggeser kurva permintaan, termasuk didalamnya pendapatan konsumen, harga barang lain, perubahan preference, dan lainnya.

Persamaan tersebut diharapkan bahwa: $\partial D / \partial P=\mathrm{Dp}<0, \partial D / \partial P=\mathrm{D} \alpha$, dan $\mathrm{D} \alpha$ dapat bernilai positif atau negatif

Fungsi penawaran

$\mathrm{Qs}=\mathrm{S}(\mathrm{P}, \beta)$

Keterangan Qs = jumlah penawaran, $\mathrm{P}=$ harga barang, dan $\beta=$ variabel yang dapat menggeser kurva penawaran, seperti harga input, teknologi, harga barang lain. Fungsi penawaran tersebut diharapkan bahwa $\partial S / \partial P=\mathrm{Sp}>0$,

$\partial S / \partial \beta=S_{\beta}, \quad$ dan $S_{\beta}=$ dapat positif atau negatif. Keadaan keseimbangan dapat tercapai pada saat:

$\mathrm{Q}_{\mathrm{D}}=\mathrm{Qs}$

Deferensial total dari masing-masing fungsi pada persamaan:

$d Q_{D}=D_{P} d P+D \alpha d \alpha$

$\mathrm{dQs}=\mathrm{S}_{\mathrm{P}} \mathrm{dP}+\mathrm{S}_{\beta} \mathrm{d} \beta$

Dalam keadaan seimbang

$\partial \mathbf{Q}_{\mathrm{D}}=\partial \mathrm{Qs}$

Persamaan tersebut dapat dicari perubahan harga keseimbangan setiap kombinasi pergeseran permintaan atau penawaran. Misalnya permintaan berubah dan penawaran tetap maka diperoleh persamaan:

$\mathrm{D}_{\mathrm{P}} \mathrm{dP}+\mathrm{D} \alpha \mathrm{d} \alpha=\mathrm{S}_{\mathrm{P}} \mathrm{dP}$

atau $\frac{\partial P}{\partial \alpha}=\frac{D \alpha}{S P-D P}$

Berdasarkan persamaan tersebut apabila $\alpha$ merupakan pendapatan, dan barang yang dimaksud adalah barang normal, maka $\mathrm{D} \alpha$ adalah positif. 
Hubungan antara permintaan dan penawaran suatu komoditi dapat menggambarkan keadaan surplus, defisit atau keadaan keseimbangan terhadap komoditi yang bersangkutan.Keadaan surplus dapat terjadi apabila jumlah penawaran lebih banyak dari jumlah permintaan.Atau keadaan surplus terjadi pada tingkat harga tertentu, dimana jumlah barang yang ditawarkan lebih banyak dibandingkan dengan jumlah permintaan, $\mathrm{Q}_{\mathrm{S}}>\mathrm{Q}_{\mathrm{D}}$. Keadaan kekurangan dapat terjadi apabila jumlah permintaan lebih besar dibanding jumlah penawaran, $\mathrm{Q}_{\mathrm{S}}<\mathrm{Q}_{\mathrm{D}}$. Keadaan keseimbangan dapat terjadi apabila jumlah permintaan sama dengan jumlah penawaran $\left(Q_{D}=Q_{S}\right)$, yakni terjadi pada saat harga keseimbangan $\mathrm{P}$ dan jumlah keseimbangan Q tercapai.Hal ini menunjukkan bahwa kenaikan pendapatan akan menambah permintaan atau menggeser kurve permintaan kekanan.

Kondisi keseimbangan, yakni harga yang dibayarkan oleh konsumen sama dengan harga yang diterima produsen atau jumlah permintaan sama dengan jumlah penawaran. Konsumen dapat memperoleh kepuasan maksimum dan produsen dapat memperoleh keuntungan maksimum.

Proses penyesuaian terhadap harga keseimbangan sangat ditentukan oleh besarnya elastisitas penawaran dan elastisitas permintaan. Apabila elastisitas penawaran lebih elastis dari pada elastisitas permintaan maka dalam penyesuaiannya, harga barang pada saat itu tidak menuju pada harga keseimbangan. Sebaliknya apabila elastisitas penawaran kurang elastis dibanding dengan elastisitas permintaannya maka dalam penyesuaiannnya harga pada saat itu akan mengarah pada harga keseimbangan.

Teori Cobweb menjelaskan mengenai harga produk pertanian yang menunjukkan fluktuasi tertentu dari musim ke musim, fluktuasi tersebut makin lama makin mengecil dan akhirnya menuju keseimbangan.Penyebab fluktuasi tersebut adalah reaksi yang terlambat (time lag) dari produsen (petani) terhadap harga.Menurut Tomek dan Robinson (1972) menyatakan bahwa siklus harga dan produksi dapat terjadi dengan siklus yang mengarah pada fluktuasi tetap (kontinyu), mengarah ketitik keseimbangan (konvergen) dan siklus menjauhi titik keseimbangan (divergen)model tersebut dikenal dengan nama model Cobweb.

Untuk menganalisis fungsi permintaan dan penawaran dapat dilakukan dengan cara (a) menggunakan persamaan tunggal (single equation) dan (b) menggunakan persamaan simultan (simultan equation system). Menggunakan persamaan simultan dapat ditentukan harga yang berlaku di pasar dan jumlah barang yang ideal pada tingkat harga tersebut, yakni ditentukan oleh perpotongan antara kurve permintaan dengan kurve penawaran.

\section{Materi dan Metode}

\section{Populasi dan Sampel}

Populasi dalam penelitian ini adalah seluruh produsen dan konsumen daging ayam broiler di Jawa Tengah, yang datanya diperoleh dan dikumpulkan melalui pencatatan secara langsung pada data Sekunder (Time series) dari tahun 1999 sampai dengan 2010 pada berbagai sumber sesuai dengan permasalahan yang diteliti. Berbagai sumber yang dimaksud adalah (1) Statistik Jawa Tengah (BPS), (2) Dinas Peternakan Jawa Tengah, (3) SUSENAS (4) Internet (5) berbagai jurnal, majalah, literatur dan sumber yang lain. 


\section{Metode}

Metode dasar yang dipergunakan dalam penelitian ini adalah metode deskriptif. Metode deskriptif adalah suatu metode dalam penelitian kelompok manusia, suatu obyek, suatu set kondisi, suatu sistem pemikiran ataupun suatu kelas peristiwa pada masa sekarang. Tujuan dari penelitian adalah untuk membuat deskriptif, gambaran atau lukisan secara sistematis, faktual dan akurat mengenai fakta-fakta, sifat-sifat serta hubungan antar fenomena yang diselidiki (Gujarati, 1999)

\section{Pembatasan Masalah dan Asumsi}

\section{a. Pembatasan masalah}

Karena luasnya permasalahan yang berkaitan dengan obyek penelitian maka untuk penyederhanaan dilakukan pembatasan masalah sebagai berikut:

(1) Secara parsial, faktor-faktor yang mempengaruhi penawaran adalah Harga daging ayam broiler, harga doc, jumlah permintaan daging ayam broiler tahun lalu, harga pakan (complete feed), Teknologi (FCR) dan wabah flu burung.

(2) Secara parsial berbagai faktor yang mempengaruhi permintaan daging ayam broiler di Jawa Tengah adalah harga daging ayam broiler, harga telur, harga beras, harga daging sapi, jumlah penduduk, pendapatan, wabah flu burung.

b. Asumsi

Sejalan dengan maksud dari pembatasan masalah diatas, diasumsikan :

(1) Jumlah penawaran daging ayam broiler sama dengan jumlah produksinya
(2) Jumlah permintaan daging ayam broiler sama dengan jumlah konsumsinya.

c. Koseptualisasi Variabel dan Pengukurannya

Pada penelitian ini dilakukan penyeragaman pengertian dalam penafsiran variabel, sehingga diharapkan dapat mendukung tercapainya tujuan. Pengertianpengertian yang dimaksud adalah sebagai berikut:

1. Permintaan daging ayam (Qd), adalah jumlah konsumsi daging ayam broiler di Jawa Tengah dan pada tahun tertentu, dinyatakan dalam satuan kilogram, $(\mathrm{kg})$

2. Penawaran daging ayam broiler (QS), adalah jumlah produksi daging ayam broiler yang dihasilkan (kg).

3. Harga daging ayam broiler (Pday)adalah harga rata-rata daging ayam broiler di pasar ( $\mathrm{Rp} / \mathrm{kg})$

4. Harga daging ayam broiler tahun lalu (Qdt-t) adalah harga rata-rata daging ayam broiler di pasar tahun lalu $(\mathrm{Rp} / \mathrm{kg})$

5. Harga barang lain

a. Barang yang sejenis yang digunakan untuk lauk

Harga barang lain adalah harga daging sapi, harga daging ayam buras dan telur adalah harga transaksi antara penjual dan pembeli yang diecerkan, yang dinyatakan dalam satuan $\mathrm{Rp} / \mathrm{kg}$.

b. Barang yang bukan dari sejenis daging dan bisa untuk saling melengkapi yaitu:

Harga beras, adalah harga transaksi antara penjual dan 
pembeli , yang dinyatakan dalam satuan $\mathrm{Rp} / \mathrm{kg}$.

6. Harga pakan (Pakn), adalah harga rata-rata pakan jadi berupa (complete feed) setiap periode pemeliharaan yang dinyatakan dalam Rp/kg.

7. Jumlah penduduk (Jp), adalah banyaknya penduduk Jawa Tengah pada tahun tertentu, yang dinyatakan dalam satuan jiwa (orang).

8. Pendapatan per kapita penduduk Propinsi Jawa Tengah (I) diperoleh dengan membagi PDRB atas dasar harga konstan dengan jumlah penduduk Propinsi Jawa Tengah.

9. Dummy Wabah Flu burung (Dwfb), adalah kondisi di Jawa Tengah saat ada wabah flu burung $\mathrm{D}_{\mathrm{wfb}}$ diberi nilai 0 , saat kondisi Jawa Tengah tidak ada wabah flu burung $\mathrm{D}_{\mathrm{wfb}}$ diberi nilai 1 .

\section{Macam dan Jenis Data}

Untuk menganalisis permasalahan dalam penelitian ini menggunakan data sekunder "time series" antara lain :

(1) Jumlah permintaan daging ayam broiler di Jawa Tengah

(2) Jumlah penawaran daging ayam broiler di Jawa Tengah

(3) Harga jenis daging, yakni harga daging dari jenis-jenis daging ayam broiler, daging ayam buras dan harga daging sapi.

(4) Harga barang lain (selain daging), yang berkaitan dengan permintaan daging ayam broiler terdiri dari barang substitusi dan komplementer. Barang substitusi daging ayam broiler adalah telur dan daging sapi, sedangkan barang komplementer adalah beras.

(5) Harga pakan (complete feed)

(6) Teknologi, jumlah produksi per jumlah pakan yang dihabiskan.

(7) Jumlah penduduk dan pendapatan per kapita.

\section{Metode Analisa}

Alat analisa yang digunakan dalam penelitian adalah dengan: regresi berganda yang diselesaikan dengan system persamaan simultan untuk mengetahui hubungan interdependensi pada kedua variabel endogen (Crutchey et al, 1999), Model simultan adalah model yang mempunyai lebih dari satu variabel tidak bebas (endogenous variabel) dan lebih dari satu persamaan, yaitu persamaan Permintaan dan persamaan Penawaran. Hubungan interdependensi menyebabkan variabel endogen yang menjelaskan (dependent explanatory variable) menjadi stokastik dan terkolerasi dengan gangguan (disturbance) dari persamaan yang muncul sebagai variabel yang menjelaskan.

Mengacu pada asumsi keseimbangan sistem COBWEB, model fungsi permintaan daging ayam broiler pada tahun $t$ didefinisikan sebagai fungsi dari permintaan harga daging ayam broiler tahun $\mathrm{t}-1$, harga daging ayam broiler tahun $t$, Secara matemetis permintaan daging ayam broiler dirumuskan sebagai berikut:

Pada persamaan simultan, fungsi penawaran dan fungsi permintaan dirumuskan sebagai berikut (Johnston, 1984).

$$
\begin{aligned}
& \text { Fungsi Penawaran : } \mathrm{Qs}=\mathrm{f}\left(\mathrm{P}^{*}, \mathrm{~A}\right) \\
& \text { Fungsi Permintaan : } \mathrm{Qd}=\mathrm{f}\left(\mathrm{P}^{*}, \mathrm{Ps}, \mathrm{I}\right)
\end{aligned}
$$

Keterangan:

Qs = jumlah penawaran, $\mathrm{P}^{*}=$ harga

keseimbangan, $\mathrm{A}=$ teknologi, 
Qd = jumlah permintaan, Ps = harga barang lain dan $\mathrm{I}=$ pendapatan.

Diasumsi bahwa fungsi penawaran dan permintaan dibentuk oleh variabel non stokastik dan komponen pengganggu. Persamaan penawaran dan permintaan yang dimaksud dapat dirumuskan sebagai berikut:

a. Persamaan fungsi penawaran $\mathrm{Q}_{\mathrm{s}}=\mathrm{a}_{0}+\mathrm{a}_{1} \mathrm{P}^{*}+\mathrm{a}_{2} \mathrm{~A}+\mathrm{U}$

b. Persamaan fungsi permintaan

$$
\mathrm{Q}_{\mathrm{d}}=\mathrm{b}_{0}+\mathrm{b}_{1} \mathrm{P}^{*}+\mathrm{b}_{2} \mathrm{Ps}+\mathrm{b}_{3} \mathrm{I}+\mathrm{V}
$$

c. Persamaan keseimbangan

$$
\mathrm{Q}_{\mathrm{s}}=\mathrm{Q}_{\mathrm{d}}
$$

Persamaan simultan disini adalah persamaan yang dibentuk pada posisi keseimbangan terseb ut. Selanjutnya untuk melakukan estimasi dari kedua persamaan tersebut maka dilakukan dengan metode Two Stage Least Square (TSLS) dengan cara sebagai

1. Mengidentikkan antara jumlah penawaran dan jumlah permintaan : $Q_{s}=Q_{d}$

$$
\begin{aligned}
& a_{0}+a_{1} P^{*}+a_{2} A+u=b_{0}+b_{1} P^{*}+b_{2} P s+b_{3} I+V \\
& a_{0}+a_{2} A+u-b_{0}-b_{2} \text { Ps }-b_{3} I-v=b_{1} P^{*}-a_{1} P^{*} \\
& a_{0}-b_{0}+a_{2} A-b_{2} \text { Ps }-b_{3} I-v=\left(b_{1}-a_{1}\right) P^{*}
\end{aligned}
$$

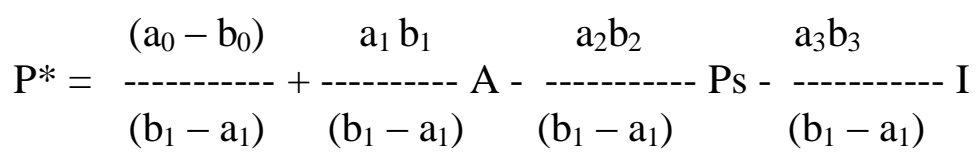

Dari persamaan tersebut dapat disusun persamaan reduce form sebagai berikut: $\mathrm{P}^{*}=\pi_{0}+\pi_{1} \mathrm{~A}+\pi_{2} \mathrm{P}_{\mathrm{s}}+\pi_{3} \mathrm{I}$

2. Memasukkan harga $P^{*}$ tersebut ke dalam persamaan struktural pertama

a. Persamaan fungsi penawaran

$$
\mathrm{Qs}=\mathrm{a}_{0}+\mathrm{a}_{1} \mathrm{P}^{*}+\mathrm{a}_{2} \mathrm{~A}+\mathrm{u}
$$

b. Persamaan fungsi permintaan

$$
\mathrm{Qd}=\mathrm{b}_{0}+\mathrm{b}_{1} \mathrm{P} \quad *+\mathrm{b}_{2} \mathrm{P}_{\mathrm{s}}+\mathrm{b}_{3} \mathrm{I}+\mathrm{U}
$$

\section{HASIL DAN PEMBAHASAN}

\section{Harga Keseimbangan Pasar Model Cobweb}

Model persamaan permintaan dan penawaran daging ayam broiler dapat diformulasikan sebagai berikut:

Penawaran daging ayam broiler :

Ln Qs = Ln a + b ln Pdayl

Permintaan daging ayam broiler :

Ln Qd = Ln c - d ln Pday

Keterangan:

Ln Qs = Penawaran daging ayam broiler
Ln Pdayl = Harga daging ayam broiler tahun lalu

Ln Qd = Permintaan daging ayam broiler

Untuk ln a dan $\ln \mathrm{c}$ masing-masing adalah konstanta, sedangkan b, d masingmasing adalah elastisitas harga penawaran, elastisitas harga permintaan daging ayam broiler.

Berdasarkan besarnya elastisitas harga permintaan dan penawaran daging ayam broiler, maka tercapainya kondisi keseimbangan sangat tergantung pada perbedaan besarnya elastisitas harga pada permintaan dan penawaran daging ayam broiler. 
Berdasarkan besarnya nilai elastisitas harga pada permintaan dan penawaran dengan model cobweb (Tomek dan Robinson, 1990) adalah:

$\mathrm{Qt}^{(\mathrm{s})}=\delta+\gamma$ Pt-1 (Supply)

$\mathrm{Qt}^{(\mathrm{s})}=\mathrm{Qt}^{(\mathrm{d})}$ (Equilibrium)

$\mathrm{Pt}=\alpha-\beta \mathrm{Qt}^{(\mathrm{d})}$ (demand)

$\frac{d p}{d q}=-\beta($ demand $)$

$\frac{d p}{d q}=\frac{1}{y}=\gamma^{-1}$ (Supply)

Kondisi slope:

\section{$(-\beta)>\left(\gamma^{-1}\right)$ divergent cycle \\ $(-\beta)=\left(\gamma^{-1}\right)$ continous cycle \\ $(-\beta)<\left(\gamma^{-1}\right)$ convergent cycle}

Hasil analisis fungsi permintaan dan fungsi penawaran daging ayam broiler adalah :

Ln Qd = 22,878** - 0,643 Ln Pday

Ln Qs $=0,961+2,218^{* *}$ Ln Pdayl

Keterangan $: * *=$ nyata $(\mathrm{P}<0,01)$

Besarnya nilai elastisitas harga permintaan daging ayam broiler $(\varepsilon d)=0,643$ lebih kecil apabila dibandingkan dengan elastisitas penawaran daging ayam broiler $(\varepsilon s)=2,218$, sehingga $\mathrm{Ed}<$ Es. Jika elastisitas penawaran relatif lebih elastis apabila dibandingkan dengan elastisitas permintaan maka harga akan menuju ke keseimbangan.

\section{KESIMPULAN DAN SARAN}

\section{Kesimpulan}

Menggunakan keseimbangan cobweb, besarnya elastisitas harga permintaan daging ayam broiler mempunyai tanda yang negatif dan bersifat in elastik (e <1), sedangkan elastisitas penawaran yang mempunyai tanda positif dan mempunyai sifat elastis. Ini memberikan arti bahwa dari perilaku konsumen dengan adanya perubahan harga pengaruhnya terhadap jumlah barang yang diminta lebih kecil sedang dari sisi produsen adanya perubahan harga pengaruhnya terhadap barang yang diproduksi lebih besar.

\section{Saran}

Perlu pengkajian yang lebih mendalam tentang perilaku konsumen terhadap perubahan harga daging yang setiap saat berubah, dan ketidakseimbangan jumlah barang antara keinginan konsumen dengan produsen.

\section{DAFTAR PUSTAKA}

Badan Pusat Statistik. 2000. Pengeluaran Untuk Konsumsi Penduduk Indonesia 2000. Jakarta.Indonesia.

Badan Pusat Statistik. 2000. Konsumsi Kalori dan Protein Penduduk Indonesia. Jakarta. Indonesia.

Badan Pusat Statistik.2010. Jawa Tengah dalam Angka. Laporan Tahunan Badan Pusat Statistik Provinsi Jawa Tengah.

Crutchley, C.E., M.R.H. Jensen, Jr. Jahera, and J.E. Raymond. 1999. "Agency Problems and The Simultaneity Decision Making The Role of Institusional Ownership". International Review of Financial Analysis, 8.2.

Gujarati, D. 1999. Ekonometrika Dasar Terjemahan (Sumarno Zaen) Erlangga.

Johnston, J. 1984. Econometric Methods. Third Edition. Mcgraw Hill. New York.

Romaully . 2010. Model Penawaran dan Permintaan Daging Ayam Ras Pedaging di Propinsi Kalimantan Selatan dengan Pendekatan 
Persamaan Simultan,

http://kopertis11.net/jurnal/MIRAND

A ROMAULLY-MODEL (Diakses

tanggal 20 Juni 2013).

Tomek dan Robinson.1990. Agriculture

Product Prices. $3^{\text {rd }}$. New York .USA.

Cornell University 